\title{
A SHORT HISTORY OF MALAYSIA
}

\author{
PART 1
}

Malaysia and Brazil has many similarities. In the 1500s the Portuguese was a mighty sea power and she went conquering faraway places. So both Brazil and Malaya were under the control of the Portuguese. Brazil is a much larger country and also nearer by sea to Portugal. So when other nations challenged the Portuguese they decided to focus on South America and so in 1640 the Dutch took over Malaya and Indonesia. By the 1700s the British began to move look towards the East for spices. They went to India and then came to Malaya. The Dutch decided to control Indonesia and so in 1780 the British took control of Malaya.

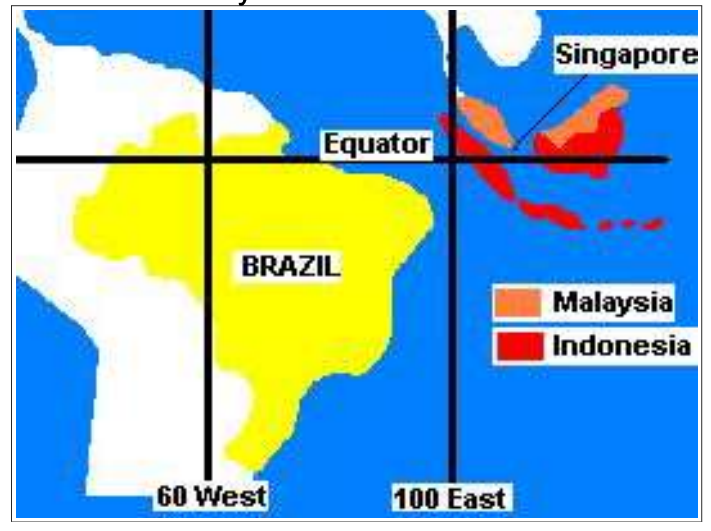

The Chinese has been roaming the East for centuries, looking for natural resources. In the 1800s when tin was an important commodity the Chinese came to look for tin. By 1840 they have started the tin industry in Malaya.

When rubber became an important commodity the British took some seedlings from Brazil and started planting them in Malaya. Both Brazil and Malaya are at about the same latitude, very near the equator, so it is not surprising that the Brazilian rubber grew very well in Malaysia.

So Malaysia became the largest supplier of tin and rubber to the world for many years to come.

After the Second World War many countries fought for independence. The Indonesian fought the Dutch and got their independence. Malaya was a little more patient and negotiated with the British until finally in 1957 it was given its independence. The British was left with the northern region of Borneo, Singapore and Brunei. In 1963 the British got the people from the British Borneo (the Southern region belongs to Indonesia), Singapore and Malaya to form a union to be known as Malaysia. And so Malaysia was formed.

Singapore being a more progressive commercial entity did not fit into the union very well and so it was decided that it is better if they go on their own. And so it left Malaysia to be an independent state.

Meanwhile the Dutch were developing the palm oil in Indonesian. In the 1960s the Indonesians were facing social instability and they looked upon the rich Dutch plantation owners as exploiters. They Dutch decided to bring their know-how to Malaysia. They help Malaysia to develop its palm oil plantation.

Palm oil cultivation became so important that many gave up planting rubber to plant palm oil instead. This is because the rubber industry is more labour intensive and profit from the oil palm is better. Also the tin industry was dying as no new tin deposits were found.

So now Malaysia is the world's number one producer of oil palm. It is also the number one producer of electronics components. Malaysia is also self-sufficient in petroleum.

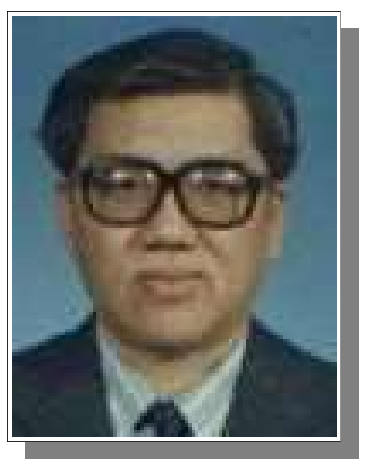

\section{Dr Ng Swee Ching \\ P.O. Box 151 \\ 80710 Johor Baru \\ Malaysia}

Tchê Química met $\mathrm{Dr} \mathrm{Ng}$ through in his site on the Internet, available at www.geocities.com/chemistry_with_dr_ng. $\mathrm{Dr} \mathrm{Ng}$ is a 58 years old Malayan professor and, for about 25 years, he taught Chemistry in the University of Malaya,but now he is retired doing and interested in doing social work.

$\mathrm{He}$ is also sending out an e-daily to those who are interested in the Association of South-East Asia (Asean). South-East Asia is one of the most vibrant econonmic region in the world today. The people are both Weatern and China, Japan, South Korea orientated. The e-daily is in English. Those who let to be included in the mailing list can make a request to $\mathrm{Dr} \mathrm{Ng}$ Swee Ching, drscng@singnet.com.sg. Please state CANews - request as the subject.

A Tchê Química conheceu o $\mathrm{Dr} \mathrm{Ng}$ através de seu site na Internet, disponível em

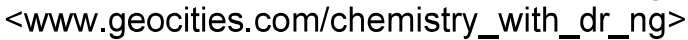

O Dr Ng é Maláio, tem 58 anos e durante 25 anos foi professor de Química na Universidade da Malásia, mas, atualmente, ele está aposentado e realizando trabalho social.

Ele também envia diariamente um jornal eletrônico para os interesados na Associação do Sudeste da Asia (Asean). O sudeste da Asia é uma das regiões econômicas mais vibrantes do mundo hoje em dia. Pessoas interessadas em ser incluídas na lista de endereços para receber o Jornal eletrônico devem escrever para o Dr Ng Swee Ching, drscng@singnet.com.sg. No campo assunto da mensagem devem adicionar o seguinte Título Please state CANews - request. O jornal CANews é escrito em Inglês. 